2021 (119-120): 121-132.

(C) A szerző(k) 2021

replika.hu/replika/119-120

\title{
„Peccsdzsem maszlinás borkányban”
}

\author{
Jakab-Benke Nándor monológja
}

\begin{abstract}
Absztrakt: A nyelvészeti etnográfiáról és antropológiáról szóló tematikus összeállítást bevezető monológ Szabó Gergely és Bodó Csanád Jakab-Benke Nándorral készített interjúja alapján készült. A monológ fó témája a Jakab-Benke által folytatott médiatevékenység nyelvi vonatkozásai, különös tekintettel az általa létrehozott Székely nyelvleckék címü sorozatra, amely „vírusvideóként” jelenítette meg a székelyföldi beszédmódokat. A monológ címe is innen származik, és nyelvi megformáltságával rámutat e beszédmódok regionális (peccs 'csipkebogyó'), nemzetközi (dzsem) és román nyelvi hatást mutató (maszlinás ’olajbogyós', borkány 'beföttesüveg') sajátosságaira.
\end{abstract}

Kulcsszavak: médiatevékenység, Székely nyelvleckék, tájszólás, akcentus, animáció 
Én egy kicsit hibrid termék vagyok. ${ }^{1}$ Édesapám egy Kolozsvár mellőli faluból származik, ez a Mezőségnek a széle, kidei, hogyha ez mond valamit, ez a falu. (Ott volt Nyírő József pap, amíg nem lett szerelmes, és nem hagyta ott egy kisasszony miatt a papi hivatást.) Édesanyám viszont székely. Sepsiszentgyörgy melletti faluból származik, és Kolozsváron találkoztak. Azért mondom, hogy hibrid vagyok, mert mi Székelyföldön nőttünk fel, ebben a kicsi faluban, és - én ezt nem tudtam megfogalmazni akkor még, s valószínúleg csak nagyon későre tudatosult -, érződött, hogy apám másképp beszél, mint mindenki más a családban és a faluban. Teljesen másféle akcentussal beszélt. Nem volt tipikus mezőségi vagy kolozsvári akcentusa, próbált „sztenderd” magyar nyelven beszélni, és ezzel szemben meg otthon, a faluban mindenki székely nyelvjárásban és székely akcentussal beszélt. Én ezzel nőttem fel, nekem ez volt a természetes, ugyanakkor meg fura is volt, hogy apám egy kicsit másképp beszél. És voltak mindig apróságok, hogy apám kijavította anyámat, például a suksuksükölést. Sokszor suksükölnek nálunk, és akkor apám mindig kijavította anyámat, hogy ne suksüköljön, és föleg úgy javította ki, hogy ezt mi halljuk, és hogy majd később mi se suksüköljünk.

Aztán persze bekerültem városra, és ott végeztem a középiskolát, Sepsiszentgyörgyön. Ott meg már annak ellenére, hogy székely kisváros, Erdély magyarlakta területeiről nagyon sok ember került oda az iparosításkor. Mert ugye a Ceauşescu-rendszernek nagyon fontos célkitűzése volt, hogy minél jobban keverje össze az embereket, hogy mindenféle homogenitást tudjanak megszüntetni. Tanárokat helyeztek ki Moldvába (meg még messzebbre) satöbbi. Ott viszont a suliban már nagyon sokféle akcentussal találkoztam, de azért mindig a sepsiszentgyörgyi székely akcentus volt az, ami a domináns igazából.

És a következö „culture shock”, vagy nem tudom mi, az akkor volt, amikor felkerültem Kolozsvárra. Ott egy évet eltöltöttem én is bölcsészkaron, magyar-angol szakos voltam kilencvenkilenctől. Ott pedig Kolozsváron a székely egyetemistákat, a székely elsőéveseket, azokat általában vagy nagyon hamar leültetik a seggükre (vagy attól függ, hogy éppen mi a domináns az illető csoportban, tehát - mit tudom én - hogyha a székelyek vannak többségben, akkor ők lesznek a többségben, ha viszont kicsit kevesebben vannak, akkor hamar leültetik őket, és van is egy ilyen frusztráció), tehát ez a székely elsőéves egyetemista frusztráció egy nagyon létező dolog ott. (Sokszor fojtják alkoholba a bánatukat.) Az egy dolog, hogy románul nem tudnak, de amikor elöször találkoznak váradiakkal meg szatmáriakkal, az aztán végképp egy „izé”, hogy mondjam? Amikor elsőévesek az egyetemisták, és konkrétan hetek, vagy hónapok telnek el azzal, hogy megszokják azt, hogy a többiek hogyan beszélnek, tehát hogy nagyon-nagyon változatos tájszólások keverednek Kolozsváron, ezt, gondolom, nem kell magyarázni.

Kolozsváron ez volt. Ott, Szentgyörgyön csírájában megtapasztaltam, hogy volt, aki egy picit másképp beszélt, de azért a székely volt a domináns mindenhol, az üzletektől elkezdve mindenhol. Az iskolában a tanárok azért próbálnak egy sztenderdebb magyart beszélni. Viszont Kolozsváron elsőéves koromban, tényleg, amikor megjelentek a szatmáriak, a váradiak, a zilahiak, mindenki másképpen beszélt. Sőt még az udvarhelyiek is, azok is egy kicsit másképp beszélnek, mint a csíkiak vagy a szentgyörgyiek, és kacagunk

1 Az eredeti interjút Szabó Gergely és Bodó Csanád készítette, monológgá szerkesztette Bodó Csanád. 
rajta, mondom, aki kisebbségben marad, az lehet, hogy frusztrált. S persze ezek alakítják egymást, tehát hogy tanulnak tájszavakat egymástól az emberek például.

Én később Kolozsváron maradtam, és ott persze románul kell érvényesülni föleg. De nagyon sok emberen láttam, akivel Szentgyörgyröl jöttünk fel annak idején, hogy levetette, nem egyből, de levetette a tájszólását. Ezt most nem rosszindulatból mondom, hanem egyszerűen tény, hogy valaki hamarabb asszimilálódik, valaki pedig később. Én a később asszimilálódó vagyok. Nem tudom, mennyire érződik, én már kívülről nem látom magam. Persze én is alkalmazkodom az illetö kontextushoz: amikor hazamegyek, akkor elökotrom a régi szavakat, de amikor feljövök ide a bölcsészkarra, Pestre, akkor lehet, hogy éppen annyira nem, szóval mindenki alkalmazkodik egy kicsit. Kicsit alkalmazkodsz a szituációhoz.

Azt kell tudni az erdélyi magyarok románoktatásáról, hogy tragikus volt, talán most kezdődnek valamiféle folyamatok, amik ezt kicsit gördülékenyebbé teszik. De az a baj, hogy van ez a román nemzeti hübrisz, amelyik nem bírja elviselni azt, hogy ne ugyanazt a román anyagot adják le a gyerekeknek. Márpedig nagyon nem azt kellene leadni, mert más, amikor nullaéves korodtól kezdve azt hallod, és utána úgy mész hét-nyolc évesen iskolába, hogy a román az anyanyelved, és akkor egy olyan tananyagot kapsz - és más, amikor úgy mész, hogy tényleg hét-nyolc évesen hallasz elöször román szavakat az iskolában. Mondjuk mi az óvodában is eljutottunk a romántanulásig, de hogy konkrétan annak a rendszernek, nem akarom azt mondani, hogy áldozata, de annak a rendszernek a terméke vagyok, aki egy nagyon szar tananyag alapján tanult meg románul a suliban. Nem az utcán, nem otthon, mert ugye Székelyföldről beszélünk, hanem az iskolában. Látszik, hogy azért tanítják a gyerekeket románul, hogy tudjanak leérettségizni belőle, nem azért, hogy később elhelyezkedjenek a munkaerőpiacon vagy boldoguljanak vagy verset írjanak - vagy mit tudom én, tudjanak udvarolni románul. Nem, hanem azért, hogy tudjanak leérettségizni, hogy őket tudják kipipálni: megtettük a dolgunkat, kezit csókolom!

Szóval nagyon-nagyon szar hozzáállás, most kezdett ez egy kicsit erodálódni, kicsit talán változni fog, egy specifikus, magyaroknak kitalált tananyagot fognak bevezetni, hogy ne az legyen, hogy úgy tanítanak nyolcéves korodtól, mintha már addig románul beszéltél volna, hanem tényleg pont mint ahogy angolt tanul az ember vagy németet vagy bármilyen más idegen nyelvet. Ez a baj, hogy „,román mint idegen nyelv”, így kéne tanítani, de nem így tanítják, hanem románt mint anyanyelvet tanítják. Mondom, ez a román nemzeti hübrisz ezt nem bírja lenyelni. S most talán meg fog változni, zárójel bezárva.

Aki ott marad Kolozsváron, ugye három-négy évet tart az egyetem, [neki] az pont arra elég, hogy megtanuljon annyira románul, hogy már elboldoguljon az utcán is, meg tudjon azért szót érteni az emberekkel. Van, aki inkább burokban nő fel, tehát azt kell tudni, hogy Kolozsváron - hatalmas város saját magához képest most már -, ha valaki nagyon magyar enklávéban akar maradni, akkor meg tudja tenni, simán. Például hogyha bölcsészkaron magyarra jársz, akkor tényleg minimalizálni tudod a románokkal való kontaktusodat, ez a helyzet. Van, aki ezt direkt csinálja, mert neki ez kényelmetlen, aztán hazamegy, viszszamegy Udvarhelyre, és ugyanúgy éli az életét tovább nyugdíjazásig, mintha semmi se történt volna. Van, aki pedig kénytelen elhelyezkedni a román munkaerőpiacon, és akkor kénytelen megtanulni kicsit jobban románul. Én mindvégig, hogy is mondjam, a magyar kultúra vonzáskörében maradtam, tehát nem mentem el - mit tudom én - multicéghez 
dolgozni, ahol románul kellett volna tanulni. De attól függetlenül én már nagyon-nagyon régóta Kolozsváron élek, úgyhogy elkerülhetetlen volt, hogy megtanuljak viszonylag jól románul. De szerintem egyből felismerhető: a románok egyből felismerik, hogyha valaki magyar, és románul beszél. Aztán majd az illetötől függ, hogy ezt mennyire értékeli. Mert van, aki ezt külön erőfeszítésként értékeli és díjazza, valaki pedig „még egy rendes román kiejtésed sincs" dologgal intézi el, tehát azért ez nagyon változatos - igazából minden kontextusfüggö, azt tudom mondani, és emberenként változik.

Az angol nekem nagyon fontos, és ezzel csak azt tudom bizonyítani, mint amit már nagyon sokan bebizonyítottak, hogy nagyon-nagyon fontos az oktatás. Mi az angolt idegen nyelvként tanultuk a suliban, mint ahogy a románt is kellett volna. És nagyon-nagyon jó angoltanárom volt, és nagyon sokat köszönhetek neki. Nem tudok és nem akarok belemenni, nem vagyok pedagógus, csak annyit tudok mondani, hogy megszerettette velünk a nyelvet. Ráéreztetett arra, hogy mi számít szépnek az angolban. Közben, ha belegondolsz, egy rettenetesen csúnya nyelv, nagyon komplikált, semmit sem úgy olvasol, ahogy le van írva, meg a francia megerőszakolta már vagy hússzor, szóval ez egy nagyon ronda nyelv. De a tanárnőnk meg tudta tanítani azt, hogy szeressük és felismerjük, hogy mitől szép. És így voltam magyar-angol szakos egy évet. Aztán kicsit kevésbé lett fontos az angol nyelv, most viszont már megint fontosabb lett, merthogy elkezdtem fordításokkal is foglalkozni.

Igen, fontos az angol. Kicsit, hogy mondjam, élek is belőle. Élek is abból a tudásból, anyagi szempontból is hasznot tudok faragni belőle. És valószínűleg ha így tanították volna a románt, akkor jobban értékelnénk a román nyelv szépségeit. Ez csak még kontraszt, hogy azt is ugyanúgy az iskolában hallottam elöször.

A forradalom után, a kilencvenes évek elején megnyíltak a határok, na nem teljesen, de mégiscsak el lehetett indulni. Jöttek oda-vissza segélycsomag-adományok, nagyobb része Magyarországról, de jöttek Hollandiából is, ahol éltek reformátusok. Mert Szentgyörgy ilyen református vidék, és a hollandok akkor küldtek ajándékcsomagot. S Magyarországról nagyon sok könyv jött. Mert ugye nem lehetett hivatalosan magyarországi könyveket vásárolni nálunk. Volt magyar nyelvű könyvkiadás Romániában a kommunizmus alatt is, persze nagyon meg volt válogatva, hogy mit lehetett kiadni. S akkor hirtelen elkezdtek özönleni a magyar nyelvü könyvek. Az emberek gyüjtötték és küldték tovább. Például a suliban osztogatták. S akkor vittem haza valami könyveket, és az egyikben szerepelt egy veszprémi család neve és címe. És elkezdtünk velük levelezni. És addig levelezgettünk, mármint hogy föleg a szüleim, merthogy én akkor hány éves voltam? Nyolc, kilenc, ilyesmi. S addig levelezgettünk, hogy meghívtak oda. És akkor először Veszprémben voltunk, nem Budapesten. Ez kábé kilencvenkettőben volt. Nagyon-nagyon fura volt. Az volt az igazi kultúrsokk, igen. Hogy ezek magyarul beszélnek, de azért teljesen másképp. Miért kell nyafogni? Miért tesznek névelőt a nevek elé? Tudod, az szerintem egyébként a németből jön, van egy ilyen tippem. Nem?

Ez volt a legnagyobb sokk egyébként, ez a „megyünk a Pistihez”, ezt a mai napig nem tudom feldolgozni. Miért kell az „a”? Miért kell ezt odatenni? Lesokkolt rendesen, de ugyanakkor meg valami hihetetlenül kitágult az univerzum: lehet menni, lehet beszélgetni, és igazából jó, egy-két vicces szón kívül megértik, amit mondok, és ez valami hihetetlen felszabadító érzés volt a furcsaságok mellett. Nekik is feltűnt néhány furcsa szó, 
hogy miért mondunk úgy egy-két dolgot, meg nekünk is megvolt az, hogy a veszprémiek miért mondanak úgy egy-két dolgot. Egyébként szerintem tipikusan azok a fogalmak viccesebbek - most nem akarok itt trianonozni, isten örizz -, de amik azóta honosodtak meg a közigazgatásban, a jogban, mert mondjuk addig azokra nem volt magyar kifejezés, és most meg már románul honosodtak meg. És itt vannak az eltérések a különböző erdélyi tájszólások és a magyarországi tájszólások között. Ugyanakkor meg találkoztam valaki Zala megyeivel, és kiderült, hogy nagyon hasonlóan beszélnek, mint a szentgyörgyiek, aztán ez is valami hihetetlen jó érzés volt. Az is megnyugtató érzés volt, hogy nem vagyunk egyedül az univerzumban.

Nagyon sokáig létezett ez a Kukker.ro nevü projekt, amit nem én találtam ki, szóval a lényeg, hogy nem pont az én fejemből pattant ki az ötlet, hogy csináljunk egy erdélyi YouTube-ot. A YouTube-nak az a lényege, nem a YouTube termeli a tartalmat, hanem a felhasználók által generált tartalomból müködik igazából. Ennek viszont az lett volna a lényege, hogy mi termeljünk tartalmat. Egyébként akkor születtek a Székely nyelvleckék, abban az időszakban. ${ }^{2}$ Hát ez már több mint tíz éve volt. Aztán meg is szűnt a Kukker mint olyan, mert nem volt értelme. A finanszírozó kihátrált a dologból, teljesen megértem egyébként, s most a YouTube-on vannak fenn ezek a videók. Az ősellenségen.

Ezek nem kifizetődő dolgok. Senki sem fog fizetni azért, hogy vicces videókat nézzen, amikor ott van az ezer millió vicces videó ingyen a YouTube-on. Egyébként talán még nem is üzleti modellként müködött az egész, hanem egyszerüen egy projekt volt, hogy csináljunk ilyesmit. S nagyon jó volt, amíg volt mecénás mögötte, utána meg az ember kell egyébbel is foglalkozzon, ami pénzt hoz.

Elmondom a sztoriját az egésznek. Én közben filmszakra is jártam, és ott volt egy óránk, animáció. Kellett egy animációt csinálni félév végére, és persze, hogy nem csináltam meg. Leadás előtti éjszaka írtam egy nagyon rövid történetet, és nagyon gagyi fröccsöntött, olcsó műanyag bábukkal megcsináltam az animációt, amiben beszélnek egymással. Ez volt A nem szabványos rénszarvas címủ animáció. ${ }^{3}$ És persze átmentem azon a tantárgyon, azzal nem is volt baj. Aztán később felraktam a YouTube-ra. Na és abból lett igazából az első mém, azt nagyon sok ember szerette, mert az volt az első videó, ahol tényleg székely tájszólásba beszélnek a karakterek, tudod? És ezt most nem izéből mondom, bölcsködésből, de tényleg nagyon sok embernek nagyon jól esett, hogy egy vírusvideó - nem mém, hanem vírusvideó -, ahol tényleg székely tájszólásban beszélnek, tehát Szentgyörgyön a mai napig ez - tényleg mindenféle álszerénység nélkül - egy kicsit kultuszvideó maradt. Erre figyeltek fel, hogy lehet nagyon olcsón csinálni nagyon vicces dolgokat. Ezért hívtak engem oda, amikor született ez az ötlet, hogy legyen egy videómegosztó ez, aminek az lett később a neve, hogy Kukker.ro, és akkor megtettek főszerkesztőnek, s annyi volt, hogy „srácok, kaptok fizetést, hozhatsz még két embert, s csináljatok heti két-három videót, s legyen minél viccesebb". Ennyi volt a feladat. Ez volt a Kukker története. Müködött hét évig.

2 A Székely nyelvlecke magyaroknak címü tízrészes sorozat első videója itt érhető el: https://www.youtube.com/ watch?v=2IQ6I1NMe7Y.

3 A nem szabványos rénszarvas címü animációs film, készítette Jakab-Benke Nándor 2006-ban. https://www. youtube.com/watch?v=rg7gBbmI9eo. 
Annak ellenére, hogy hibridként definiáltam magam a legelső mondatban, ha visszapörgettek, annak ellenére én székelynek tartom magam, mert ott nöttem fel, ott szocializálódtam. Azt tanultam, azt tudom, és ezt tudom a leghamarabb előszedni, és nem is volt kérdés, hogy másképp beszéljenek a bábok. Én szerintem nem tudnám jól eljátszani azt, hogy pesti bábokat mozgassak, mert kilógna a lóláb. Megpróbálhatok, most bocsánat, de affektálni egy picit, vagy valami, tudod, de nagyon látszana.

Ennek készült volna - végül nem csináltam meg lustaságból - egy folytatása, ahol lett volna egy kolozsvári karakter, mert közben megkaptam Mózest Amerikából. Hú, hát az nagyon groteszk. Amerikában árulnak bibliai karaktereket, action figure-ben, tehát játékszerként. S abból kiindulva akartam folytatást csinálni, hogy Mózes legyen egy kolozsvári magyar, aki kolozsváriasan beszél, érted, és akkor „kettéválassza a tengert”, és nem tudom, így beszélne tényleg, katasztrofális. Csak nem csináltam meg, mert lusta voltam. És szerintem az is érződne, hogy igazából kifogástalanul csak ezen az akcentuson tudok beszélni úgy, hogy ne lógjon ki egy értő fül számára a lóláb. Ahhoz Pesten kell élnem öt évet, hogy kifogástalanul el tudjak játszani egy pestit.

Ez volt az internet hőskora. Az erdélyi magyar internet hőskora, annek ez része volt. A Székely nyelvleckéknek pedig van egy nagyon konkrét eredettörténete. Nem tudom, emlékeztek-e, 2007-8 környékén volt egy magyar film, aminek az a címe, hogy Kalandorok. Rendezte Paczolay Béla. Nem rossz film, díjakat is nyert, viszont valami olyasmi a története, hogy Haumann Péter alakítja az egyik izét, és hogy a fia Magyarországon él, de ő gyergyói, és - midlife crisis vagy mi a lófasz - hazamegy az apjához, hogy beszélgessenek. Az apuka elvileg gyergyói és elvileg a cselekmény Gyergyóban játszódik, és ott elvileg beszélget a fia az apjával, de úgy beszélnek, mint két pesti színész. Érted? És én ezen akadtam ki igazából, hogy még egyszer elmondom, a Kalandorok címü film miatti felháborodásom az oka az egésznek. Esküszöm. Egyébként hogyha megfigyelitek, az amerikai filmekben az ilyesmit nagyon komolyan veszik. Tehát ott nem müködik az, hogy ha egy film Texasban játszódik, és eljön az izé, mondjad már, Hugh Grant vagy ki a lófasz Londonból, és ott ne texasiasan beszéljen, hogyha az ő karaktere texasi. Ezt nem lehet megúszni. Akkor be kell magolni azt a tájszólást, van language coach meg mindenféle. Akkor az olyan kell legyen, az cájsz kell legyen, tudod? Magyar filmekben megengedik maguknak, hogy elvileg Gyergyóban játszódik, és pont úgy beszélnek, mint hogyha Pesten, az első vagy a második kerületben üldögélnének egy teraszon. És nagyon-nagyon zavart, hogy pedig meg lehetne csinálni, hogy ugyanúgy dokumentálva van, hanganyagot lehet kérni, lehet gyakorolni. Lehet, hogy még a színésznek is egy nagyon fasza kihívás lenne, hogy székelyül beszéljen egy kicsit. S konkrétan ezért csináltam ezeket a videókat, ez úgy forrott bennem egy ideig, ez a dolog. És persze humoros formát akartam keresni neki, mert az, hogy valaki csak felháborodik, az hosszú távon csak nevetséges lesz.

Egyrészt a felháborodás, másrészt meg teljesen a kényszer szülte valami volt. Mert emlékszem, mondtam az előbb, hogy volt egy heti kvóta, hogy két vagy három videó, nem tudom mennyi, amit le kellett adni. Emlékszem, hogy ez valami november környéke volt talán. Mindenki le volt betegedve, takony, influenza, és én maradtam, egyedül kellett megcsinálnom az aheti anyagot, és ezt tök egyedül csináltam egy nyamvadt mikrofonnal, és Google image search-csel és egy vágóprogrammal. Ennyi volt alapvetően. Kicsit, mondom, kényszermegoldás volt. Lehet, hogyha valami narratívabb formát találtam volna 
neki, például vannak ilyen apróságok, hogy van egy rész, ahol verekedünk, kicsit narratívabb, ugye, valami cselekmény is van abban, lehet, hogyha ilyen formában született volna, akkor nem lesz ekkora siker, mert valahol a forma esetlensége is vicces. Tehát az, hogy csak képek jelennek meg egymás után, és a képek közti kontraszt ad egy pluszt. Szerintem ezért is tudott müködni, nemcsak az a reveláció, hogy jaj de vicces a székely tájszólás a pestinek, a veszpréminek, a pécsinek, hanem a képek egyszerüsége vagy esetlensége és egymásmellettisége, az adja neki meg a pluszt. És persze a székely akcentus, amire biztosan nagyon sokszor nagyon sokan úgy csodálkoznak rá, hogy „jé, ez tényleg így van? ez nem egy paródia?” Vagy „nem egy vicc?”. Mert egyébként nem vicc, az a része nem vicc. Ami ott elhangzik és megmutatódik, az tényleg úgy van.

Hogy mondjam nektek? Ezt is otthonról hoztam, egy részét a faluból. Ezeket az ember felszedi, hallja, bármennyire is pironkodunk, hogy izé meg templomba járó református emberek vagyunk, meg nem tudom, de elhangzik egy-egy ilyesmi. Jó, van, amit én találtam ki már, meg valami direkt ilyen nagyon izé, konstrukció, de például a „bassza meg a csincs az ötöt", na az a csincs [cinci], az az öt románul. S ebben nagyon benne van, hogy egyébként, ha belegondoltok, egy nagyon erös erdélyi melankólia, ebben a „bassza meg a csincs az ötöt"-ben. A román ötös bassza meg a magyar ötöt. S nem tudom, miért az öt, lehetne tíz vagy valami, szerintem a ritmusa miatt van ez, mert hogy milyen jól kijön, hogy „bassza meg a csincs az ötöt”. Na ezt például otthon hallottam, szerintem családi környezetben elöször.

Ennek is vannak szintjei. Istent azért csak akkor emlegetjük, amikor tényleg nagyon nagy baj van. Egyébként meg lehet elégedni az alacsonyabb rendü szentekkel - meg a különböző számokkal ezek szerint. Persze, van ennek egy fokozása. Nem lehet lelőni az összes patronodat csak azért, mer belerúgtál egy fiókos szekrénybe. Minimum fel kell boruljon egy szekér széna ahhoz, hogy Istent előszedd, de akkor meg már lehet, akkor lehet. Ha felborul a szénás szekered, akkor szidhatod Istent is akár.

$\mathrm{Az}$ volt a fö szelekciós elv, hogy viccesen nézzenek ki egymás mellett. Hogy legyen egy-egy poénsorozat abban is, hogy hogyan kerülnek egymás mellé, tehát hogy a borkány $s$ akkor a peccsdzsem maszlinás borkányban. Hogy legyen egy plusz a sorrendben. $\mathrm{Ne}$ az legyen, hogy csak random egymás után összevissza a szavak, hanem legyen egy egymásutánisága, dramaturgiája, hogyha szabad így fogalmaznom, az egésznek. Nem mindig sikerült persze, de azért törekedtem erre. És persze még nagyon-nagyon sok szó lett volna, de egyszerüen nem akartam folytatni, olyan kínos, amikor már a nem tudom, hány milliomodikat csinálod, az olyan kínos. Le akartam kerekíteni egy adott ponton. Elöször, amikor megcsináltam, azt gondoltam, hogy csak az az egy marad, és őszintén meglepődtem, hogy mekkora vírus lett belőle akkor, tehát hogy néhány napon belül mindenki írt, hogy „váó”, és nem tudom, mi. Ahhoz képest nagy sikere lett, és meglepődtem, s akkor azt mondtam, na jó, ezt még kéne fejni egy kicsit. S akkor kitaláltam egy menetrendet, hogy legyen tíz. De már eleve tízet akartam, tehát azt mondtam, hogy utána nem lesz több. Aztán persze csináltam románt magyaroknak meg magyart románoknak, nem tudom, az már későbbi projekt volt, azok szerintem nem is voltak annyira jópofák.

A Nyelvleckék-ben az valami nagyon különleges volt ilyen szempontból, hogy jöttek oda emberek az utcán, hogy „szia, láttam a Nyelvleckéket, és jót kacagtunk” s nagyon sok ilyen feedbackem volt. Az nagyon egyedi valami volt, hogy akkora sikere legyen 
a Nyelvleckék-nek. És nagyon sok feedback jött. „Ezt láttuk, kacagtuk, megmutattuk a Kanadában élő rokonoknak, és ott is kacagtak." Igen, nagyon sok ilyen jött egyébként, külföldön élő magyaroktól, tehát hogy nem a Kárpát-medencében élő magyaroktól, hogy kacagtak, de közben sírtak is, meg hogy „milyen jó volt látni”, és az amerikai, meg a kanadai nagybácsi is, ,jaj de szuper volt”. Nagyon sok ilyen visszajelzés is jött, igen.

Egy magyarországi magyarnak vagy egy nem székelyföldi magyarnak azért van humorforrás benne, az akcentus miatt. Egy picit rá is játszok az akcentusra, és ahogy mondom, egy kicsit deklamálós stílusban, ahogy elmondom a szavakat, abban is van egy plusz humorforrás. A székelyföldi székelyeknek meg azért, mert magukat hallják benne. Tehát hogy már két kapura lehet játszani, a szavakkal, és azzal, ahogyan a szavak el vannak mondva. Azonkívül pedig ott van ez, amit mondtam, a képeknek az esetlensége, úgy tünik, mintha egymásra lennének, egymás után lennének odahajigálva. A betűtípus sem valami nagy vasziszdasz, csak egy random font. És lehet, hogy ezáltal azt érzik, hogy ez az ők videóik. Nincs annyira megkonstruálva, van egy ilyen esetlenség, ilyen hétköznapiság benne talán. Nem, nem tudom, öszintén. Nem tudom ezt nagyon megfejteni. Ha megfejtettem volna, akkor csupa ilyen videót csináltam volna, de nagyon sok szar videót csináltam, amit aztán megnéztek ötvenen. Ennyi, szóval nem sikerült ezt meglovagolni sajnos.

Örülök, ha értékelik az emberek és kacagnak. Annak kevésbé örülök, ha mit tudom én, valami olyasmit látnak bele, ami nincs benne, vagy tipikusan ezek a „miért tettél bele román szavakat?" Azért az ilyesminek nem örülök annyira, de lehet, hogy még ilyen szempontból is jó, hogy szembesül a valósággal. Tehát ez a helyzet. Tudom, hogy nagyon sok magyarországiban olyan kép él, hogy Erdély a Tündérország, ahol mindenki fehér gyolcsban úszkál az égen, és Csaba királyfival direkt sms-vonalon kommunikálunk, meg nem tudom mi, de ez izé, bullshit.

$\mathrm{Az}$ az igazság, hogy nekem annyira elmegy az életkedvem a kommentolvasás alatt, tényleg annyi bunkó van, ne haragudjatok, hogy ezt így mondom, annyi bunkó ember kötelességének érzi, hogy valami hülyeséget leírjon. Az emberekről azt kell tudni, hogy ha nagyon meg akarnak sértődni valamin, akkor úgyis megsértődnek, és nagyon faszán tudnak maguknak csinálni valami kifogást. Kifogásgyártásban az ember zseniális. Az ember egy kifogásgyártó gép alapvetően. Ebben egyezzünk meg. És hogyha meg akarnak sértődni azon, hogy mért nem raktam be ezt a szót, vagy mért raktam be ezt a szót, vagy hogy „ez a szó ez román!”, akkor úgyis meg fognak sértődni, tehát nincs mit csinálni. Egy idő után effektíve kezdtem nem olvasni. Úgyhogy most jelen pillanatban azt se tudom, hány komment van, mik vannak alatta, mert tudom, hogyha bekapcsolom, csak felhergelem magam, és semmi értelme nincs elcseszni egy fél napot azzal, hogy ezen túrázom magam. De nem olvasom a kommenteket az újságokban sem, megnyitom a napilapot, mit tudom én, az Indexet vagy bármit, elolvasom a cikket, és kattintom ki, kész. Kommenteket nem olvasok. Mérgező. Tényleg, szomorúan hangzik, de mérgező a magyar kommentkultúra.

Volt ilyen is, hogy mért raktam bele román szavakat. Hát azért, mert most már, nem tudom, hány éve kölcsönhatásban él ez a két nyelv. Sajnálom, ez van, és nagyon sok szót átvettek egyébként ők is a magyarból, amint az látszik, hogyha megnézitek a Magyar 
nyelvlecke románoknak sorozatban, abból nagyon sok minden ilyen kiderül. ${ }^{4}$ Viszont a magyar is nagyon sok szót átvett a románból. Ez van. És ezek egyébként még tájanként is tudnak változni, ez a szép. Egyébként a románban is van egy nagyon erős homogenizációs törekvés, hogy a román nyelv az legyen szép és mindenféle befolyástól mentes, és az ilyen nagyon erdélyizmusokat, amik között a legtöbb magyar eredetű, azt próbálják ők is számüzni.

És hogy mondjam, román és román között is hatalmas különbségek vannak, vannak tősgyökeres erdélyi románok, akik még tudnak is magyarul, meg ha nem komplett, akkor legalább néhány szót azért tudnak, és vannak a nem erdélyiek, akiknek ez ugyanakkora kultúrsokk, vagy még nagyobb kultúrsokk, mint nekem, amikor elöször a veszprémieket hallottam. És szerintem ez is nagyon szomorú, hogy a román nyelvet is próbálják erdélyietleníteni. Ott annak is megvan egy nagyon erős specifikus erdélyi változata, az erdélyi román, és az is változik egyébként tájegységenként. Egy móc egy kicsit másképp beszél, mint a máramarosi, és viszont a közös bennük, hogy nagyon sok magyar kölcsönszavuk van ezek által. És akkor „nem, nem!” Próbálják az iskolában nagyon-nagyon határozottan uniformizálni a román nyelvet; márpedig ne legyenek! És ez nagyon ártalmas. Minden nyelvnek szerintem nagyon ártalmas az, hogy jön valami bizottság, és megmondja, hogy te ne így beszélj, hanem úgy beszélj velem. Ki is vagyok én? A csávó, aki összerakta a helyesírási szabályzatot? Jaj, Istenem, ez is egy izé, hogy most már nem lehet dupla ssz-t használni, hanem sz-sz! Ez most az új helyesírás! Mi a faszomat jelent? Már bocsánat! Ki találta ezt ki? Miért kéne engedelmeskedjek neki? Jó, zárójel bezárva. Én szerkesztőként mondom, mert naponta szerkesztek szövegeket: hogyan toldalékoljunk idegen szavakat? Ami eddig volt, az miért nem volt jó? Most miért kellett változtatni rajta? Bocsánat, befejeztem.

Hát a Székelyföldön élő román, az muszáj tudjon egy kicsit magyarul, tehát azt nem tudja megúszni. Például Udvarhelyen vagy Szentgyörgyön. Nekem van Szentgyörgyön ilyen ismerősöm, és kitünően beszél magyarul, de székely akcentussal. És ugyanez volt, hogy eljött Budapestre, itt él a csaj, és ugyanúgy sokk volt neki, hogy jaj, ez egy kicsit más magyar, mint amit otthon tanultam a magyaroktól. Van ilyen is. És a székelyföldi román ezeket már azért jobban látja, de mondjuk egy kolozsvári román szerintem csak annyit érez, hogy ez a csávó nem anyanyelvi román. Nem román anyanyelvü, de mit tudom én, lehet, hogy kifogástalan a szókincse vagy valami, de hogy az úgy érződik a magánhangzókon.

Volt egy botrány. Nem tudom, emlékeztek-e, olvassátok-e az erdélyi sajtót. Egy kovásznai, ami eleve olyan város, hogy székelyföldi, de azért már elég sok román van, egyharmada kábé román, valami hetven-harminc az arány. Vegyes iskolában játszódott a történet, és a magyarok március 15-én szabadnapot kaptak, és a román gyerekek felháborodtak, hogy miért van a magyaroknak szabadnapja. Valami ilyen faszság miatt ott egy kislány feltette a román pántlikát, és akkor hirtelen a román nacionalista sajtó: „jaj, ez a tizenhét éves kislány most nemzeti hős lett", hirtelen, egy nap alatt. Annyira undorítóak

4 Feltehetőleg itt a Román nyelvlecke székelyeknek című tízrészes sorozatra utal (https://www.youtube.com/playl ist?list=PLYefdYiBYHDVfTFvn_8f5ncWAePZ40Enq). 
ezek a sztorik, és igazából ez azután volt egy pár héttel, és azért raktam fel ezt a pántlikát, merthogy ez arra akart utalni. ${ }^{5}$

Hogy felismerték-e a tájszólásomat? Valószínüleg. Nem tudok kibújni a bőrömből teljesen. Tehát mondom, nem tudnám teljesen eljátszani. És lehet, hogy egy székelyföldi boltost, úgymond, át tudok verni. Egyébként ez annyira összetett helyzet. Nagyon egyszerünek tűnik, mert egy csávó bemegy, vesz egy kenyeret. Ilyen egyszerünek tünik. De nem az, mert ott van a kamera, ott van a pántlika, ott van az akcentus, tehát hogy ezek mind befolyásolják azt a helyzetet. Hogy akkor vajon a néni az román-e? Mert van arra is ugyan esély, hogy Szentgyörgyön ugyan, de román legyen az elárusító néni. Hogyha román, akkor szentgyörgyi-e, tehát hogy mennyire tősgyökeres szentgyörgyi, mert lehet, hogy tényleg tíz éve érkezett a Regátból és még nem tud jól, vagy nem tudja felismerni, hogy akkor ki milyen románsággal beszél. Ez nagyon-nagyon komplex helyzet, ha egy picit belegondolunk. És persze hogy nem gondoltunk bele, amikor elkezdtük ezt az egészet forgatni, ez csak egy hirtelen ötlet volt. Merthogy létezik ez, hogy mindig mondják a románok, hogy „igen, mert bemész Székelyföldön, és nem kapsz kenyeret”. Ez egy viszszatérö hülyeség és urban legend. Vagy nem tudom, hogy hívják ezeket, abszolút visszatérő hülyesége a román nacionalistáknak, hogy a Székelyföldön nem szolgálják ki őket kenyérrel. Van ilyen, ez egy ilyen „thing”. És akkor ez egy ellenvideó akar lenni, hogy lám, mégiscsak kiszolgálják. És őszintén nem gondoltam abba is bele, ezen kívül, hogy akkor most a tájszólással hogy lesz. Persze, hogy érződik, egyből érződik. A kommentekben is, főleg a román nyelvű kommentekben egyből mondják, hogy „hát nem tudom, nem tudsz senkit ezzel az akcentussal átverni”. Ez az egyik, az egyik legkorábbi észrevételük a román kommentelőknek, hogy „ezzel az akcentussal senkit nem tudsz átverni”. Igen, na. Sajnos.

Ez igazából dokumentumfilmnek is felfogható azon kívül, hogy heccvideó. Dokumentálja azt a helyzetet, tehát ami ott történik, az le van filmezve. Ahonnan kiraktak, onnan kiraktak, ahol kiszolgáltak, ott kiszolgáltak - utána volt kellemetlen, amikor valaki felismert a buszon, és hogy elvileg követett hazáig, és kiírta valami fórumra, hogy ez a csávó ott lakik Kolozsváron, X utca, X környékén. Akkor egy kicsit betojtam egy időre, de nem lett semmi, semmi baj, hál' Istennek.

Ezen kacagtak az emberek. Nagyon sok jó érzésü román van, ezen simán tudott röhögni. Van egy Sabin Gherman nevü tévés személyiség Kolozsváron, nagyon szeparatista, Erdély-centrikus, transzilvanista, aki még annak idején, a 2000-es évek közepén írt egy kiáltványt, „tele a tököm Romániával”, és hogy szakadjon el Erdély. De más súlya van, amikor egy román mondja, tudod, mint amikor összeül öt részeg magyar, és elkezd ilyeneket mondani, hogy „vesszen Trianon”. És más, amikor egy román értelmiségi azt mondja, hogy „elegem van Bukarestből és a bukaresti parlamentből”. Szóval ez a csávó meghívott később a műsorába, de nem mentem el, nem akartam továbbdagasztani a dolgot.

5 A Kenyeret kértünk románul Székelyföldön - Am cerut pâine in Secuime című videót Jakab-Benke Nándor sepsiszentgyörgyi pékáruboltokban vette fel 2013-ban, fején román „trikolor-kendővel” (https://www.youtube.com/ watch?v=40_4aVkGVrM). 
A másodiknál, ott már jobban kiütöttem a biztosítékot. ${ }^{6}$ Mert sokan érezték úgy, még a magyarok közül is, hogy „de miért kéne bárki beszéljen a kenyérárusító nénik közül, legalábbis, magyarul”? Mondom, de nem is ez volt a cél! Hát nem is egy felmérést akartam készíteni, hanem egyszerüen, ha már ott volt ez a videó, akkor úgy éreztem, hogy muszáj megcsinálni a párját. $\mathrm{Na}$ hát ennyi volt a projekt. Tehát nem akartam én ezzel semmiféle szociografikus mélységü dolgot megmutatni, hogy akkor tudnak vagy nem tudnak, vagy mindenki tud, vagy ez a helyzet vagy nem tudom mi, hanem elsősorban ez egy ilyen hecc valami, na. Tehát hogy nem mentem be az összes üzletbe. Rejtett kamerát kellett volna használni, persze, ez a másik. Másképp viselkednek az emberek, amikor látják a kamerát. Ezek mind „késő bánat”-dolgok. De szerintem az alapvető céljukat a videók elérték, ami pedig az volt, hogy az emberek egy kicsit gondolkozzanak ezzel, hogy mi az, ami egyértelmü egy városban, mi az, ami nem egyértelmü, s mi az, ami felé törekedni kéne.

Tehát hogy ne legyen az, hogy most akkor egyértelmü Szentgyörgyön valami. Vagy hogy ne higgyenek ezeknek a hülyeségeknek, konkrétan. Mert nagyon sokan egyszerüen soha nem jártak Székelyföldön a románok közül, és ezt a bullshitet elhiszik, hogy „odamész, és nem kapsz kenyeret”! Régi hülyeség, a 70-es évekből ered. Nem tudom, honnan, lehet, hogy egyvalakinek részegen volt egy nagyon szar tapasztalata, és akkor tudjátok, hogy müködik ez, elindul, és akkor egy kis hógolyóból lesz egy nagy lavina, és aztán lesz a lavinából egy urban legend, hogy „a románokat nem szolgálják ki Szentgyörgyön!” És a kenyér, kenyér! Fontos, hogy ez kenyér.

Te, mondok én nektek még egy valamit. Vannak olyanok, elneveztem ezeket „sleeper magyaroknak". Főleg Kolozsváron van nagyon sok, de olyan erdélyi városokban, ahol hagyományosan nagyon sok magyar van vagy volt, az öregek, a 60 feletti generáció, nagyon sokan nemcsak hogy értenek magyarul, de tudnak is beszélni, egészen meglepően jól. Lehet, hogy családi, munkahelyi satöbbi, ki tudja, milyen egyéb okok miatt, de nagyon sokan. Viszont nem hangoztatják. Tudod, ezért hívom öket sleeper magyaroknak, hogy nem az van, hogy találkozol egy románnal, bemutatkozol, hogy „szia, Nándor vagyok” vagy „Pista vagyok”, és akkor tört magyarsággal ugyan, de kedvesen megszólal, hogy „szia, nem tudom, mi, gyere, igyunk meg egy kávét”. Nem, titokban tartják, és legváratlanabb helyzetekben derül ki. Párat tapasztaltam ilyet az évek folyamán, hogy románok egészen meglepő helyzetekben megszólalnak magyarul, és nagyon erős akcentussal, de el tudják mondani, amit akarnak. És bazmeg, miért nem használod ezt a tudást? Ez egy plusz, így csak több vagy, mint a másik. És nem tudom, lehet, hogy van egy ilyen stigma, őszintén nem tudom, mert azért ennyire nem kérdeztem ki az illetőket. De egészen meglepő dolgok tudnak kiderülni. És nagyon sokan értik, tehát nem érdemes szidni a románokat Kolozsváron, mert föleg az öregek megértik, hogy mit mondasz. Akkor is, ha nem tudják szó szerint leírni vagy valami.

6 A Kenyeret, kokárdával, Kolozsváron - Am cerut paine ungureşte, la Cluj című videó 2013-ban készült, ezen Jakab-Benke Nándor Bocskai-ruhában, kokárdával a mellén, magyarul beszélt az eladókhoz a boltokban (https:// www.youtube.com/watch?v=gztMgueG47w). 
Legutóbb például jött egy magyarországi szakmai csoport, akikkel nem lehetett angolul kommunikálni. Merthogy magyarországiakról beszélünk, akik nem tudnak angolul. Bocsánat! És odahívott engem és egy kollégámat egy illető, hogy segítsünk kommunikálni a magyarországiakkal. Odamentünk, és kiderült, hogy csak azért volt ránk szükség, hogy szóljunk, hogyha valami nagyon nagy hülyeséget mondana az illető, mert az illető hirtelen kinyílt, és - én már vagy öt-hat éve ismerem, nem jól, csak szakmai találkozásokon keresztül - hirtelen elkezdett magyarul beszélni. De hogy izé, számokat megfogalmazni, hogy tudod, négyszázhuszonhatezer vagy valami, tudod, egész konkrét dolgokat el tudott mondani. És hirtelen végigpörgettem, hogy mondtam-e én ezelött a néni elött olyasmiket, amik kompromittálók lehetnek. Hát van ilyen.

Egyébként ezt, hogy bementem, és kértem magyarul kenyeret, ezt sem én találtam ki alapvetőleg. Anyum ezt néha heccből csinálja, mert ő is Kolozsváron végzett, és amikor édesanyám volt Kolozsváron egyetemista, akkor még nem volt ennyire felborítva a nemzetiségi arány, és föleg a központban simán lehetett magyarul boldogulni, tudod? És anyám most is ezt csinálja, néha heccből bemegy, és csak magyarul hajlandó megszólalni, és mindenhol kiszolgálják. Egyébként erre utal, hogyha láttátok még A nem szabványos rénszarvas-t, az, „hogyha pénzetek van, akkor minden nyelven tudunk”. Ez a helyzet. Mert ezt láttam élőben, hogy „ööö, nem tudunk”, de amikor megvillantod a százlejest, akkor egyből jön a varázslat. 